\title{
CHARLES UNIVERSITY, PRAGUE RADIOCARBON MEASUREMENTS I
}

\author{
JAN ŠILAR \\ Department of Hydrogeology and Engineering Geology, Charles University \\ Albertov 6, CS-12843 Praha 2, Czechoslovakia \\ and \\ RICHARD TYKVA
}

Institute of Organic Chemistry and Biochemistry, Czechoslovak Academy of Sciences Flemingovo nám 2, CS-16610 Praha 6, Czechoslovakia

\begin{abstract}
We converted to $\mathrm{CO}_{2}$ samples of organic materials, Quaternary carbonate rocks and carbonates extracted from groundwater. We measured ${ }^{14} \mathrm{C}$ radioactivity in a proportional counter with an effective volume of $723 \mathrm{ml}$ filled to $0.28 \mathrm{MPa}$. A mechanical box with an inside cylinder of a plastic scintillator, $4 \mathrm{~cm}$ thick, arranged in anticoincidence provides the shielding. We present a review of radiocarbon ages of Quaternary and archaeological samples.
\end{abstract}

\section{INTRODUCTION}

The Charles University radiocarbon dating laboratory has been in operation at the Department of Hydrogeology and Engineering Geology, Faculty of Science, since 1972. The laboratory was established to conduct research in radiocarbon dating groundwater, the Quaternary period and archaeology.

Our equipment consists of a vacuum line processing samples to carbon dioxide which is used as filling gas, a proportional gas counter with massive and anticoincidence shielding and measuring and recording devices.

\section{SAMPLE PROCESSING}

After macroscopic impurities are removed from the samples, they are dried and crushed if necessary. Carbonates are removed by boiling in $2 \% \mathrm{HCl}$ and washing until a neutral reaction occurs. Humic acids are dissolved with a $2 \% \mathrm{NaOH}$ solution at $80^{\circ} \mathrm{C}$ for 24 hours and precipitated from the solution with $2 \%$ hydrochloric acid. The sample is finally washed in distilled water until neutral and dried. The dried sample is then burned in a double quartz tube in an oxygen stream using cobaltocobaltic oxide as the catalyst, purified on silver wool and absorbed in $\mathrm{CO}_{2}$-free $2 \%$ sodium hydroxide solution with $\mathrm{CuSO}_{4}$ added to remove $\mathrm{H}_{2} \mathrm{~S}$. From the alkaline solution, the $\mathrm{CO}_{2}$ is evolved by acidification with citric acid and subsequently dried and purified by sequentially trapping in dry ice liquid nitrogen, hot $\mathrm{CuO}$ and hot $\mathrm{Ag}$ traps to remove traces of sulphur and nitrogen. Afterwards, the $\mathrm{CO}_{2}$ is filled into the detector. All the chemicals were p.a. ${ }^{1}$ grade purity.

Carbon is extracted from groundwater in the field either by precipitating bicarbonates by barium chloride as barium carbonate (water sampling for ${ }^{14} \mathrm{C}$ analysis, IAEA nd) or by trapping the bicarbonates on a basic ion exchanger (Crosby \& Chatters 1965). In either case, $\mathrm{CO}_{2}$ is evolved by phosphoric acid and is absorbed in $\mathrm{CO}_{2}$-free sodium hydroxide solution with added $\mathrm{CuSO}_{4}$. Afterwards, $\mathrm{CO}_{2}$ is evolved by citric acid and treated as above.

Calcium carbonate samples of, eg, sediments and shells, are treated in the same way as $\mathrm{BaCO}_{3}$ extracted from groundwater.

${ }^{1}$ pro analysi = for analysis, in analytical chemistry, means the purity grade 


\section{MEASURING TECHNIQUES}

After chemical treatment and purification, the sample, in the form of $\mathrm{CO}_{2}$, is expanded into a proportional counting system consisting of an internal proportional gas counter and anticoincidence and massive shielding.

All construction materials of the counting and shielding equipment were selected and checked for low radionuclide contamination (Tykva 1974: 177-179). The detector section of the counting arrangement in a mobile light-tight case consists of an internal proportional counter surrounded by an anticoincidence cylinder of a plastic scintillator, $4 \mathrm{~cm}$ thick, with photomultipliers at both ends. The counter in the case is connected by tubing to the filling line and, through a cable, to a preamplifier. The counter, of $723 \mathrm{ml}$ effective volume, is made from a copper tube purchased from an old brewery pipeline in which a silver-coated tube of pure quartz is inserted as a cathode. The central anode is a $30 \mu \mathrm{m}$ diameter molybdenum wire.

The light-tight case is inserted into a shielding box consisting of several layers. The outer lead was purchased from 60- to 80-year-old water-supply pipelines, the inner low-level lead from Bolidens A S, Sweden. Both materials were processed in special melts with protection against fallout and radionuclide contamination. Soft steel covering the lead was manufactured analogously on special order. Polymers containing dispersed boric acid are used as neutron shielding. The details of the arrangement were described earlier (Šilar \& Tykva 1977).

At $0.28 \mathrm{MPa}$ filling pressure of pure $\mathrm{CO}_{2}\left(83 \mathrm{mmol} \mathrm{C}\right.$ at $\left.20^{\circ} \mathrm{C}\right)$, we obtain a $400 \mathrm{~V}$ working plateau with a slope of $<1 \%$, working voltage of $5.35 \mathrm{kv}$ and a background of $1.92 \pm 0.03 \mathrm{cpm}$. The count rate of 0.95 oxalic acid standard "modern" is between 10.5 and $10.8 \pm 0.1 \mathrm{cpm}$.

The results of ${ }^{14} \mathrm{C}$ measurements are calculated to ${ }^{14} \mathrm{C}$ ages using a Hewlett-Packard 9845 computer. Corrections are incorporated for barometric pressure, room temperature, dilution of sample if necessary, initial ${ }^{14} \mathrm{C}$ activity of groundwater samples and $\delta^{13} \mathrm{C}$.

${ }^{14} \mathrm{C}$ ages are calculated using the Libby half-life of $5568 \pm 30$ years. Counting errors are expressed at $1 \sigma$ confidence level. Calibrated ages, if presented, were calculated according to Damon, Long and Wallick (1972) before the new calibration curves (Stuiver \& Kra 1986) were published.

\section{ARCHAEOLOGIC SAMPLES}

\section{Egypt}

Samples of Egyptian origin were submitted mostly by Eugen Strouhal, National Museum, Prague, from the Náprstek Museum collections of Asian, African and American cultures, a section of the National Museum in Prague. Samples were also submitted from other museums that contributed to the exposition of mummies at the National Museum in 1971 and from the findings of the Czechoslovak Institute of Egyptology, Charles University, in Egypt. Other sources are also indicated.

\section{CU-38. Coffin wedge}

Sample A 3263 of the Natural History Inst Slovak National Museum, Bratislava. Tamarisk wood (Tamarix articulata V) (Březinová \& Hurda 1976).

General Comment: sample was diluted with inactive $\mathrm{CO}_{2}$ due to small amount of available wood. Coffin allegedly originated during Saitic period, lasting until beginning of Late periods (664-500 BC), according to Egyptologic dating by M Verner (Strouhal \& Vyhnánek 1979). 
Comment: mummy wrapping supplied by Museum of Fine Arts, Philadelphia, USA, for autopsy carried out by international team, Feb 1, 1973, Wayne State School of Medicine, Detroit. Sample was labelled PUM II. Dated to $2120 \pm 70 \mathrm{BP}(170 \pm 70 \mathrm{BC}$, Cockburn et al 1975) by R Stuckenrath, Smithsonian Institution.

CU-88. Mummy wrapping $2770 \pm 120$

Part of mummy wrappings, sample no. P 624 c from Náprstek Museum, Prague.

Comment: well-preserved tissue was identified as flax (Strouhal, pers commun, 1979). According to embalming techniques, mummy P $624 \mathrm{~b}$ should date to Third Intermediate period, 1087-664 BC. According to Egyptologic dating of coffin by M Verner, mummy should date to Greek period, 332-31 BC (Strouhal \& Vyhnánek 1979). Calibrated age, $1028 \pm 144$ BC, agrees with age derived from embalming techniques rather than with date of coffin. Hence, possibility that older mummy was displaced into newer coffin cannot be excluded (Šilar 1979).

CU-89. Mummy wrapping

$3290 \pm 130$

Part of mummy wrappings P 623 c, dark disintegrating flax cloth, from Náprstek Museum.

Comment: mummy could not be dated by examining embalming techniques due to bad preservation of mummy. Egyptologic dating by $\mathrm{M}$ Verner assigns coffin to Greek period, ie, 332-31 BC (Strouhal \& Vyhnánek 1979). Neither calibrated, $1691 \pm 160$ BC, nor uncalibrated age of sample agrees with style of coffin. Displacement of older mummy into newer coffin seems more probable here than for $\mathrm{CU}-88$.

\section{CU-79. Block of wood}

$2770 \pm 140$

Sample P 4662 is from Egyptian coffin from collection of Náprstek Museum. Dated to provide authenticity of sample, which proved to be genuine, made during Third Intermediate period (1087-664 BC).

\section{Abusir series}

Samples from archaeologic site on edge of Western Desert above Abusir $\left(29^{\circ} 54^{\prime} \mathrm{N}\right.$, $31^{\circ} 13^{\prime} \mathrm{E}$ ), royal cemetery of 5th Dynasty, $30 \mathrm{~km}$ south of Cairo on west bank of Nile River. Site was investigated by Czechoslovak Institute of Egyptology, Charles University. Coll and subm by E Strouhal. Wood samples identified by Březinová and Hurda (1989).

CU-413. Abusir J 1628

$2360 \pm 170$

Wood (Ficus sp) from coffin of Tomb J 1628, from area around mastaba of Ptahshepses, secondary cemetery.

CU.414. Abusir J 1555

$2070 \pm 160$

Wood (Acacia arabica) from coffin of Tomb J 1555, from area around mastaba of Ptahshepses.

CU-437. Abusir A 15 P 5448

$2490 \pm 150$

Linen of mummy wrappings, P 5448, from Burial A 15 inside mastaba of Ptahshepses. Sample from Náprstek Museum, Prague. 
Comment: dated to compare sample from inside mastaba with two samples from tombs situated around mastaba. We proved contemporaneity of samples using $2 \sigma$ (Šilar 1989).

CU-415. Abusir 1/XX/76

$3290 \pm 170$

Wood from coffin. Isolated tomb south of mastaba of Princess Khekeretnebti.

Comment: this tomb was ca $1 \mathrm{~km}$ south of mastaba of Ptahshepses; result points to beginning of New Kingdom.

\section{Saqqara series}

Textiles and charcoal buried in shafts and chapels of tomb of Horemheb, Saqqara $\left(29^{\circ} 51^{\prime} \mathrm{N}\right.$, $31^{\circ} 14^{\prime} \mathrm{E}$ ) were investigated by Egypt Exploration Society, London and Antiquity Museum Leyden, in joint expedition. Coll and subm by E Strouhal.

CU-484. Saqqara I D

$2450 \pm 150$

Charcoal from Shaft I, Room D, mixed with bones.

CU-488. Saqqara I F

$2790 \pm 150$

Charcoal from Shaft I, Room F, mixed with bones.

CU-489. Saqqara IV N

$4360 \pm 160$

Charcoal from Shaft IV, Room N, mixed with burials N 1 and N 2 .

CU-490. Saqqara II A 59

$2540 \pm 220$

Linen covering convexity of Skull S 9 found in Shaft II, Room A.

Comment: sample CU-489 is distinctly different from CU-484, -488 and -490 , which confirms older age of original burial in Shaft IV, Room N compared with other samples. Date is even too old if time of construction of tomb in second half of 14th century BC is considered. Wood that yielded charcoal was apparently very old re-used piece. Other three samples were mutually similar. Their mean age falls in Third Intermediate period, 1087-664 BC.

\section{Kalabsha and Wadi Qitna series}

Samples of two close archaeologic sites, Wadi Qitna $\left(23^{\circ} 33^{\prime} \mathrm{N}, 32^{\circ} 55^{\prime} \mathrm{E}\right)$ and Kalabsha $\left(23^{\circ} 34^{\prime} \mathrm{N}, 32^{\circ} 55^{\prime} \mathrm{E}\right)$ were investigated by joint Charles University and Náprstek Museum expeditions. Coll and subm by E Strouhal (1984).

CU-132. Kalabsha KS t K 20/57

$1500 \pm 100$

Fragments of wood probably from funeral bed.

CU-133. Wadi Qitna WQ t 407

$1730 \pm 120$

Fragments of wood probably from funeral bed.

CU-134. Wadi Qitna WQ $\mathbf{t} 74$

$1620 \pm 100$

Fragments of wood probably from funeral bed. 
Comment: all samples belong to pre-Christian Ballana (X group) culture existing in Nubia from 2nd half of 3rd century until beginning of 6th century.

\section{Iraq}

CU-75. Aqar Quf

$3330 \pm 140$

Stalks of reed coll by J Šilar identified as Phragmites australis (Cav) (Kosinová, pers commun, 1976) from straw bands reinforcing adobe structure of ziggurat at western border of Baghdad $\left(33^{\circ} 20^{\prime} \mathrm{N}, 44^{\circ} 20^{\prime} \mathrm{E}\right)$.

\section{CU-141. Aqar Quf}

$3220 \pm 110$

Stalks of reed, origin same as CU-75.

Comment: according to al-Tikriti (1970), Aqar Quf was founded by King Kurigalzu I at beginning of 15 th century BC during Kassite period.

CU-180. Tell es-Sawwan

$$
7240 \pm 150
$$

Charcoal from Tell es-Sawwan at Samara $\left(34^{\circ} 12^{\prime} \mathrm{N}, 43^{\circ} 53^{\prime} \mathrm{E}\right)$, Iraq. Lumps of charcoal up to $5 \mathrm{~mm}$ in diameter with some admixture of silt. Subm by Fuad Safar, Directorate of Antiquities, Baghdad, Iraq.

Comment: dated by Theresa Carter, University Museum, Philadelphia, Pennsylvania as P 856 charcoal lumps from gypsum pit, Level 3, Floor 3, 1.5m below surface - at $7299 \pm 86$ (Fuad Safar, pers commun, 1973).

\section{GEOLOGIC SAMPLES}

Kuwait

Oolitic sediments and shells from Persian Gulf coast of Kuwait. Samples coll by F Picha at Mena Saud $\left(28^{\circ} 44^{\prime} \mathrm{N}, 48^{\circ} 28^{\prime} \mathrm{E}\right)$, Al-Khiran $\left(28^{\circ} 39^{\prime} \mathrm{N}, 48^{\circ} 28^{\prime} \mathrm{E}\right)$ and coastal cliff south of Al-Khiran $\left(28^{\circ} 33^{\prime} \mathrm{N}, 48^{\circ} 28^{\prime} \mathrm{E}\right)$.

\section{CU-74. Al-Khiran}

Shells of living lamellibranchs from beach.

$$
\begin{array}{r}
\delta^{14} \mathrm{C}=105.07 \pm 1.85 \mathrm{pMC} \\
\delta^{13} \mathrm{C}=+1.0 \% 0
\end{array}
$$

CU-70. Al-Khiran

$$
380 \pm 160
$$

Recent oolitic sand from top of present barrier beach, ca $7 \mathrm{~m}$ asl, ooids including cement.

\section{CU-99. Al-Khiran}

$1570 \pm 120$

$\delta^{13} \mathrm{C}=+4.8 \%$

Younger oolitic limestone from ridge ca $6 \mathrm{~m}$ asl forming ancient barrier beach, ooids; cement was separated.

\section{CU-109. Al-Khiran}

$1990 \pm 130$

Younger oolitic limestone, from same sample as $\mathrm{Cu}-99$, inner part of ooids; cement was separated. 
CU-97. Coastal cliff $\quad 4030 \pm 140$

Layer of older oolitic limestone, ca $10 \mathrm{~m}$ asl, ooids; cement was separated.

CU-110. Coastal cliff

Older oolitic limestone, inner part of ooids; from same sample as CU-97.

CU-98. Coastal cliff

$3070 \pm 130$

$\delta^{13} \mathrm{C}=+4.0 \%$

Older oolitic limestone, separated cement from between ooids; from same sample as CU-97.

CU-73. Al-Khiran

$22,850 \pm 1220$

Ridge of quartz oolitic sandstone, ca $9 \mathrm{~m}$ asl, ooids.

CU-137. Al-Khiran

$2870 \pm 110$

Inner part of shells of fossiliferous horizon, ca $1 \mathrm{~m}$ asl.

$\delta^{13} \mathrm{C}=+2.9 \%$

CU-182. Al-Khiran

$1990 \pm 110$

Inner part of shells of fossiliferous horizon, ca $1 \mathrm{~m}$ asl.

$\delta^{13} \mathrm{C}=+2.5 \%$

CU-138. Mena Saud, quarry

$2930 \pm 110$

Inner part of shells of fossiliferous horizon.

$\delta^{13} \mathrm{C}=+4.1 \%$

CU-181. Mena Saud, quarry

$3520 \pm 120$

Inner part of shells of fossiliferous horizon.

$\delta^{13} \mathrm{C}=+2.5 \%$

Comment: oolitic sediments form ridges parallel to coast. Oldest sediments are found inland; younger ones are located progressively closer to beach (Pícha 1978). CU-99, -109, -97, -110 and -98 relate to respective samples. Inner part of ooids showed lowest ${ }^{14} \mathrm{C}$ activity and cement between grains, highest. ${ }^{14} \mathrm{C}$ activity corresponds to general stratigraphy and position of sediments. ${ }^{14} \mathrm{C}$ ages of the Pleistocene sediments seem to be very low due to recrystallization of aragonite. Lower ${ }^{14} \mathrm{C}$ age of cement indicates that atmospheric $\mathrm{CO}_{2}$ was involved in subaerial diagenetic process. ${ }^{14} \mathrm{C}$ age of well-preserved mollusk shells seems to be lower than their allegedly Pleistocene age (Šilar 1980). Emergence rate of shore is between one and several millimeters per year which corresponds to rate of emergence recorded for mouth of Persian Gulf and Qatar (VitaFinzi 1979).

\section{Cuba}

Corals of the Jaimanitas Formation

Corals from Rincón de Guanabo region $\left(23^{\circ} 08^{\prime} \mathrm{N}, 82^{\circ} 11^{\prime} \mathrm{E}\right)$ west of Havana, Cuba. Coll and subm by V Náprstek, Dept Geol, Charles Univ. Dated as part of stratigraphic study of Jaimanitas Formation (Náprstek 1978).

CU-90. Guanabo

$28,500 \pm 1500$

Diploria strigosa. 
CU-92. Guanabo

$17,800 \pm 450$

Acropora sp.

CU-94. Guanabo

$24,000 \pm 1100$

Heliastrea sp.

Comment: all three samples were prepared of single block of unaltered rock from which prisms of pure carbonate of coral skeleton were cut for ${ }^{14} \mathrm{C}$ and generic determination. Coral limestones of Jaimanitas Formation should be dated according to youngest date of Acropora sp, 17,800 \pm 450 $\mathrm{BP}$, which corresponds stratigraphically to Upper Wisconsin and not to Sangamonian interglacial, as assumed previously. Geological explanation of considerable scatter of ${ }^{14} \mathrm{C}$ dates of samples is that rock-forming corals are bioclasts of various ages that were repeatedly redeposited.

\section{Czechoslovakia}

Tufa samples

\section{Svatý Jan pod Skalou series}

Tufa from Svatý Jan pod Skalou $\left(49^{\circ} 59^{\prime} \mathrm{N}, 14^{\circ} 10^{\prime} \mathrm{E}\right)$ from Holocene stratotype profile studied by V Ložek (1967), were dated paleontologically by means of mollusks. Coll by V Ložek (1967) and J Šilar. $\delta^{13} \mathrm{C}$ was measured at Institut für Radiohydrometrie (Rauert, pers commun, 1975). ${ }^{14} \mathrm{C}$ and paleontologic ages were correlated. ${ }^{14} \mathrm{C}$ ages were calculated assuming initial activity was $70 \%$ modern ${ }^{14} \mathrm{C}$. This value was adopted from initial activities of karst groundwaters in Central Europe as determined by MA Geyh (1972), and has been considered equal to activity of spring water from which tufa precipitated. Spring contains modern water at present.

\section{CU-4. Svatý Jan pod Skalou}

$3700 \pm 190$

Yellowish white porous tufa from Layer $37,0.30 \mathrm{~m}$ above base of outcrop.

\section{CU.5. Svatý Jan pod Skalou}

Yellowish white foam sinter from Layer 32, 2.80-2.95m above base of outcrop.

Comment: age of Layer 37 is Epiatlantic (Kovanda, pers commun, 1975). ${ }^{14} \mathrm{C}$ and paleontologic ages agreed assuming the ${ }^{14} \mathrm{C}$ activity was $70 \%$ modern ${ }^{14} \mathrm{C}$.

\section{Vyšné Ružbachy series}

Tufa from Vyšné Ružbachy $\left(49^{\circ} 18^{\prime} \mathrm{N}, 20^{\circ} 34^{\prime} \mathrm{E}\right)$.

\section{CU-285. Fossil compact tufa}

$38,700 \pm 6850$

$\delta^{13} \mathrm{C}=+8.1 \%$

Sample J 29 subm by V Hanzel, Geol Survey GÚDŠ, Bratislava. $\delta^{13} \mathrm{C}$ was measured by Demovič, Hoefs and Wedepohl (1972). ${ }^{14} \mathrm{C}$ age is uncorrected.

CU-145. Modern porous tufa on green plants

$40.01 \pm 1.82 \mathrm{pMC}$

Coll by J Šilar. Apparent ${ }^{14} \mathrm{C}$ age is $7360 \pm 150 \mathrm{BP}$, used for correcting ${ }^{14} \mathrm{C}$ age of CU-285. 
Comment: Vyšné Ružbachy tufa precipitates from warm springs containing $\mathrm{CO}_{2}$ of endogenic origin. Water circulates in confined system in Triassic limestones covered with Paleogene flysch, recharge area of which is located on slopes of High Tatra Mts $19 \mathrm{~km}$ west of springs. We have dated tufa to Pleistocene.

CU-179. Písek

$$
5390 \pm 130
$$

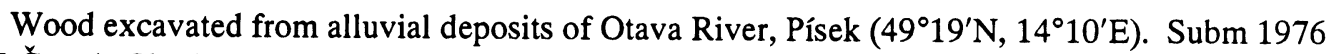
by J Černý, Charles Univ. Sample was used as reference.

Comment: comparative dating at Institute of Nuclear Research, Debrecen, resulted in Deb-159: $5340 \pm 160$ (Szalay-Csongor, pers commun, 1981).

\section{Valča series}

Clayey calcium carbonate sediments (mud), foam sinter (tufa) and embedded fragments of wood from limnic Holocene sequence in valley in Carpathians at Valča $\left(49^{\circ} 03^{\prime} \mathrm{N}, 18^{\circ} 53^{\prime} \mathrm{E}\right)$ were dated. Deposit is Holocene stratotype and was also dated using malacologic, paleobotanic and paleomagnetic methods. Samples for ${ }^{14} \mathrm{C}$ dating were collected by V Ložek and J Šilar from deposit by erosion in concave bank of creek. Aim was to correlate ${ }^{14} \mathrm{C}$ age determinations of wood, tufa and mud. Samples were treated in standard way (see SAMPLE PROCESSING, above). These results are arranged from top to bottom layers as described by Vaškovský and Ložek (1976). Depths are reported in meters below surface.

CU-610. Valča

$6260 \pm 190$

Wood from Layer 14, 6.0m.

CU-641. Valča

$7300 \pm 210$

Wood from Layer 14, 6.0m.

CU-605. Valča

$8150 \pm 220$

Foam sinter from Layer $14,6.0 \mathrm{~m}$

CU-618. Valča

$8180 \pm 200$

Foam sinter from Layer 14, 6.0m; same sample as CU-605.

CU-630. Valča

$5600 \pm 180$

Wood from Layer $15,6.20 \mathrm{~m}$.

$\delta^{13} \mathrm{C}=-29.4 \%$

CU-187. Valča

$5790 \pm 140$

Wood from Layer $15,6.20 \mathrm{~m}$.

CU-606. Valča

$10,390 \pm 450$

Mud from Layer $15,6.20 \mathrm{~m}$. 
CU-639. Valča

$10,400 \pm 330$

Mud from Layer 15, 6.20m; same sample as CU-606.

$\delta^{13} \mathrm{C}=-7.4 \%$

CU-649. Valča

$7330 \pm 190$

Wood from Layer $21,6.8 \mathrm{~m}$.

CU-643. Valča

$5650 \pm 180$

Wood from Layer $22,8.1 \mathrm{~m}$

$\delta^{13} \mathrm{C}=-27.2 \%$

CU-645. Valča

$6180 \pm 190$

Wood from Layer $22,8.1 \mathrm{~m}$.

$\delta^{13} \mathrm{C}=-26.8 \%$

CU-647. Valča

$9710 \pm 240$

Mud from Layer 22, 8.1m.

CU-629. Valča

$8830 \pm 210$

Mud from Layer $24,8.55 \mathrm{~m}$.

CU-644. Valča

$7798 \pm 210$

Wood from Layer $25,8.55 \mathrm{~m}$.

$\delta^{13} \mathrm{C}=-29.4 \%$

CU-185. Valča

$7430 \pm 150$

Wood from Layer $25,8.85 \mathrm{~m}$.

CU-616. Valča

$10,700 \pm 260$

Foam sinter with sandy tufa from Layer $31,10.20 \mathrm{~m}$.

CU.637. Valča

$11,650 \pm 300$

Foam sinter with sandy tufa from Layer $31,10.30 \mathrm{~m}$.

$\delta^{13} \mathrm{C}=-8.3 \%$

CU-617. Valča

$10,950 \pm 250$

Sandy tufa from Layer $32,11.6 \mathrm{~m}$.

CU-638. Valča

$11,050 \pm 280$

Sandy tufa from Layer $32,11.6 \mathrm{~m}$.

$\delta^{13} \mathrm{C}=-6.2 \%$

Comment: carbonate sediments consist partly of clay $t y$ earth material with plastic consistency tich in calcium carbonate (mud or marl according to conventional sedimentologic terminology) and of intercalations of tufa (foam sinter and sandy tufa). In Layers 14-25, wood is abundant as scattered fragments of branches or as standing tree trunks. ${ }^{14} \mathrm{C}$ dating of wood has shown that Atlantic/Boreal border, which had been considered to be in Layer 22, according to paleontologic dating, should be shifted somewhat lower below Layer 25 . Deposit originated as limnic sediments in small lake behind barrier of tufa which was later destroyed by erosion. ${ }^{14} \mathrm{C}$ dating of clayey 
sediment (mud) has not proven reliable due to contamination by allochthonous clastic calcium carbonate. Similar ages of thick sequence of sediments without systematic increase with depth show very rapid sedimentation. Occurrence of carbonate sediments together with Atlantic-age wood agrees with paleontologic dating and provides evidence that these sediments originated during humid climatic period as indicated by foam sinter precipitation in mid-European karstlands (Ložek 1985).

\section{REFERENCES}

Březinová, D and Hurda, B 1976 Xylotomic examination of timber from ancient Egyptian coffins: Zeitschr Ägyptische Sprache Altertumskunde 103: 139-142.

1989 Xylotomic analysis. In Strouhal, E and Bares, L, eds, The secondary cemetery in the mastaba of Ptahshepses at Abusir. Czech Inst Egyptology Pubs, Charles Univ, in press.

Cockburn, A, Barraco, RA, Reyman, TA and Peck, WH 1975 Autopsy of an Egyptian mummy. Science 187: 1155-1160.

Crosby, JW, III and Chatters, RM 1965 New techniques of water sampling for carbon 14 analysis. Jour Geophys Research 70(12): 2839-2844.

Damon, PE, Long, A and Wallick, EI 1972 Dendrochronologic calibration of the carbon-14 time scale. In Rafter, TA and Grant-Taylor, eds, Internatl conf on ${ }^{14} \mathrm{C}$ dating, 8th, Proc. Wellington, Royal Soc New Zealand: 44-59.

Demovic, R, Hoefs, J and Wedepohl, KH 1972 Geochemische Untersuchungen an Travertinen der Slowakei. Contrib Mineral Petrol 37: 15-28.

Geyh, MA 1972 Basic studies in hydrology and ${ }^{14} \mathrm{C}$ and ${ }^{3} \mathrm{H}$ measurements. Internatl Geol Cong - Hydrogeology, 24th, Montreal: 227-234.

IAEA, nd, Sampling of water for ${ }^{14} \mathrm{C}$ analysis. Vienna.

Ložek, V 1967 Sv Jan pod Skalou. In Klieve, H, ed, Holozäne Binnenwasserkalke und klastische Hangsedimente im Böhmischen Karst. Probleme und Befunde der Holozänstratigraphie in Thürigen, Sachsen und Böhmen. Quartärkommittee der DDr, INQUA Subcommission on Holocene, Berlin, Prague: 168-174.

1985 The site of Soutěska and its significance for Holocene climatic development. Československý kras 36: 7-22.

Náprstek, V 1978 Radiometric age and genesis of the Jaimanitas Formation in the Rincón de Guanabo region, Cuba. Věstník Ústředního ústavu geol 53: 19-28

Pícha, F 1978 Depositional and diagenetic history of Pleistocene and Holocene oolitic sediments and sabkhas in Kuwait, Persian Gulf. Sedimentology 25: 427-450.

Strouhal, E 1984 Wadi Qitna and Kalabsha South, vol I. Archaeology, Praha, Charles Univ: 316p.

Strouhal, E and Vyhnánek, L 1979 Egyptian mummies in Czechoslovak collections: Acta Mus Natl Pragae 35B: 199p.

Stuiver, $\mathrm{M}$ and $\mathrm{Kra}$, RS, eds, 1986, Calibration issue. Internatl ${ }^{14} \mathrm{C}$ conf, 12 th, Proc. Radiocarbon $28(2 \mathrm{~B}): 805-1030$.

Silar, J 1979 Radiocarbon dating of some mummy and coffin samples. In Strouhal, E, ed, Multidisciplinary research on Egyptian mummies in Czechoslovakia. Zeitschr Ägyptische Sprache Altertumskunde 106: 82-87.

1980 Radiocarbon activity measurements of oolitic sediments from the Persian Gulf. In Stuiver, M and Kra, RS, eds, Internatl ${ }^{14} \mathrm{C}$ conf, 10 th, Proc. Radiocarbon 22(3): 655-661.

1989 Radiocarbon dating. In Strouhal, E and Bareš, L, eds, The secondary cemetery in the mastaba of Ptahshepses at Abusir. Czech Inst Egyptology Pubs, Charles Univ, in press.

Silar, J and Tykva, R 1977 Radiocarbon dating laboratory of the Charles University, Prague: Methods and results. In Low radioactivity measurements and applications, Bratislava. Slov pedagog nakl: 331-334.

al-Tikriti, AK 1970 Archaeological restoration at Aqar Quf 1960-1961. Sumer 26(1\&2): 73 (in Arabic).

Tykva, R 1974 Die Bestimmung geringer Radioaktivität. In Simon, H, ed, Messung von Radioaktiven und stabilen isotopen. Berlin, Springer Verlag: 173-198.

Vaškovský, I and Ložek, V 1976 Guide to excursion in the Holocene of the West Carpathians. In INQUA Commission for the Study of the Holocene, 6th, Proc: 1-110.

Vita-Finzi, C 1979 Rates of Holocene folding in the coastal Zagros near Bandar Abbas in Iran. Nature 278(5706): 632-634. 